\title{
Normal pubertal development in a female with carbohydrate deficient glycoprotein syndrome
}

\author{
M Pineda, C Pavia, M A Vilaseca, I Ferrer, T Temudo, A Chabas, H Stibler, J Jaeken
}

University Hospital of Sant Joan de Déu, Barcelona, Spain, Department of Neuropaediatrics M Pineda

T Temudo

\section{Department of Endocrinology} C Pavia

Department of

Biochemistry

M A Vilaseca

I Ferrer

Institute of Clinical

Biochemistry,

Barcelona

A Chabas

\section{Department of}

Neurology, Karolinska

Hospital, Stockholm,

Sweden

H Stibler

Department of

Paediatrics, University

Hospital Gasthuisberg

Centre for Metabolic

Diseases, Leuven

Belgium

J Jaeken

Correspondence to:

Dr Mercé Pineda, Servei de Neuropediatria, Hospital

Universitari Sant Joan de

Déu, Carretera d'Esplugues

s/n, 08034-Barcelona, Spain.

Accepted 4 October 1995
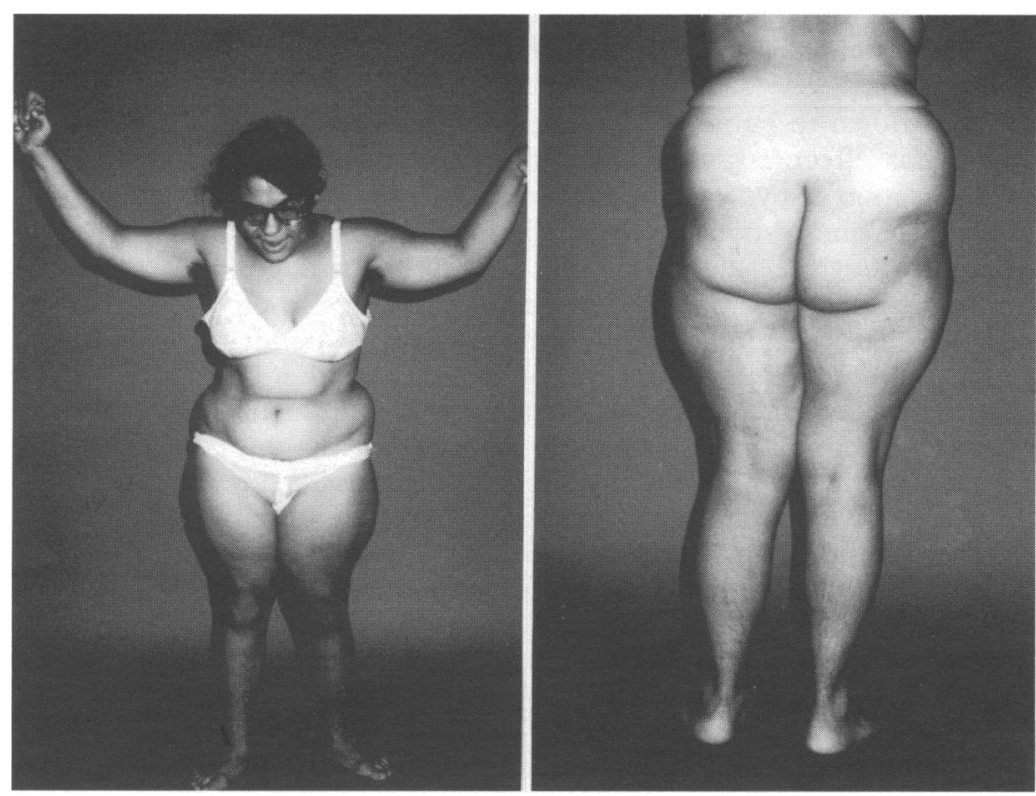

Patient at the age of 17 years old showing a coarse face, hypotrophic legs, and fat accumulations on forearms and buttocks.

Keywords: carbohydrate deficient glycoprotein syndromes, sialotransferrins, pubertal development.

Carbohydrate deficient glycoprotein (CDG) syndromes are genetic multisystemic diseases characterised by a deficiency in the carbohydrate moiety of glycoproteins. ${ }^{12}$ CDG syndrome type $I$ is the most common of the three described variants. All reported females with CDG syndrome type I have hypergonadotropic hypogonadism with absent or delayed pubertal development. ${ }^{34} \mathrm{We}$ report the first Spanish patient with a CDG syndrome.

\section{Case report}

This girl was the first child of unrelated, healthy parents. She was born after a normal pregnancy, at 36 weeks' gestation, with a birth weight of $2000 \mathrm{~g}$.

At the age of 8 months she presented with severe psychomotor retardation and hypotonia with normal reflexes. A computed tomogram showed dilated ventricles and hypoplastic

\begin{abstract}
A girl is reported who presented with many of the clinical and biochemical characteristics of type I carbohydrate deficient glycoprotein syndrome. Unusually, however, she experienced a normal pubertal development.

(Arch Dis Child 1996; 74: 242-243)
\end{abstract}


Isoelectric focusing of serum sialotransferrins showed a cathodal shift similar to the pattern of CDG syndrome type I: increased asialotransferrin (4\%; normal value $<2 \%$, type I: $2-32 \%)$ and disialotransferrin (27\%; normal value $<9 \%$; type I: $23-36 \%$ ), and decreased tetrasialotransferrin $(49 \%$; normal value $50-65 \%$; type I: $12-48 \%$ ). Trisialotransferrin and pentasialotransferrin fractions were normal. Activities of lysosomal enzymes in serum were within the normal range except for $\beta$-hexosaminidase, $\beta$-glucuronidase, and $\beta$-mannosidase which showed moderate hyperactivity $(\times 1 \cdot 8)$. Among the enzymatic activities studied in cultured skin fibroblasts, $\beta$-glucuronidase, arylsulphatase- $A, \beta$-glucocerebrosidase, and $\beta$-mannosidase were slightly but significantly increased.

Results of combined stimulation with thyrotrophin releasing hormone, gonadotrophin releasing hormone, and growth hormone releasing hormone showed a normal pubertal pattern: maximum value of $10.8 \mathrm{IU} / 1$ for luteinising hormone, $8.6 \mathrm{IU} / \mathrm{l}$ for follicle stimulating hormone, prolactin $2674 \mathrm{mU} / \mathrm{l}$, oestradiol $162 \mathrm{pmol} / \mathrm{l}$, growth hormone $100 \mathrm{mU} / \mathrm{l}$, and thyroid stimulating hormone $14.2 \mathrm{mU} / 1$. Serum concentrations of free thyroxine and triiodothyronine were $16.6 \mathrm{pmol} / 1$ (normal range 9.5-25.0 $\mathrm{pmol} / \mathrm{l}$ ) and $1.4 \mathrm{nmol} / \mathrm{l}$ (normal range 1.3-3.9 nmol/1), respectively. Antithyroglobulin and antiperoxidase antibodies were negative. Plasma concentrations of insulin like growth factor-I, growth hormone binding protein, and binding protein of insulin like growth factor were normal.

\section{Discussion}

This patient, the first one reported from Spain, presents a number of features of CDG syndrome type I: severe psychomotor retardation, alternating convergent strabismus, myopia, axial hypotonia, ataxia, seizures, abnormal subcutaneous fat distribution, pectus carinatum, hypotrophy of the legs, olivopontocerebellar hypoplasia, peripheral neuropathy, and retinitis pigmentosa. Serum glycoprotein abnormalities, decreased serum albumin and low density lipoprotein cholesterol, increased cerebrospinal fluid protein, and the serum sialotransferrin isoform pattern, are consistent with this diagnosis. ${ }^{12}$ However, there are also differences the most important being normal pubertal development. All reported girls with CDG syndrome type I have had hypogonadism with absent or delayed pubertal development. Whether this is due to a defect at the level of the ovaries or to a combined hypophyseal ovarian dysfunction remains to be determined. ${ }^{1-4}$

In our patient clinical, biochemical, and imaging data pointed towards normal ovarian function and development, except for the fact that the right ovary could not be seen on ultrasonography. Other endocrinological differences were the normal growth hormone and insulin concentrations, both in basal conditions and after stimulation. This is contrary to intermittent increases reported in other patients with CDG syndrome type I. Also at variance with type I was the persistence of pronounced abnormal subcutaneous fat distribution into adolescence, normal blood protein $\mathrm{C}$ concentration, and normal activity of arylsulphatase-A in serum associated with increased activity of some lyosomal enzymes in fibroblasts. CDG syndrome type I has recently been localised to chromosome $16 \mathrm{p} 13 \cdot 1-13 \cdot 12 .{ }^{7}$ However, so long as its basic defect remains unknown we cannot be certain whether our patient represents a variant of type I (for example a mosaic defect sparing the hypophyseal-gonadal axis) or a 'new' type. Studies of glycoprotein glycan structures and enzymatic studies are planned.

We thank Fundaçao Calouste Gulbenkian for the grant to Teresa Temudo and the Swedish Medical Research Council (grant No 07212) for supporting H Stibler. This work was partly supported by the Belgian Nationaal Fonds voor Wetenschappelijk Onderzoek (grant 3.0115.94).

1 Jaeken J, Carchon $\mathrm{H}$, Stibler $\mathrm{H}$. The carbohydrate-deficient glycoprotein syndromes. Pre-golgi and golgi disorders. Glycobiology 1993; 3: 423-8.

2 Stibler H, Blennow G, Kristiansson B, Lindehammer $H$, Hagberg B. Carbohydrate-deficient glycoprotein syndrome: clinical expression in adults with a new metabolic disease. $¥$ Neurol Neurosurg Psychiatry 1994; 57: 552-6.

3 de Zegher F, Jaeken J. Endocrinology of the carbohydratedeficient glycoprotein syndrome type I from birth through adolescence. Pediatr Res 1995; 37: 395-401.

4 Kristiansson B, Stibler H, Wide L. Gonadal function and glycoprotein hormones in the carbohydrate-deficient (CDG) syndrome. Acta Paediatr 1995; 84: 655-60.

5 Stibler H, Jaeken J, Kristianson B. Biochemical characteristics and diagnosis of the carbohydrate-deficient glycoprotein syndrome. Acta Paediatr Scand 1991; 375 (suppl): protein

6 Stibler H, Cederberg B. Diagnosis of the carbohydratedeficient glycoprotein syndrome by analysis of transferrin in filter paper blood spots. Acta Paediatr 1993; 82: $55-9$

7 Martinsson T, Bjursell C, Stibler H, et al. Linkage of a locus for carbohydrate-deficient glycoprotein syndrome type I (CDG 1) to chromosome $16 \mathrm{p}$, and linkage disequilibrium to microsatellite marker D16S406. Human and Molecular Genetics 1994; 3: 2037-42. 